\title{
PREVALENCE OF SPHINCTER OF ODDI DYSFUNCTION IN PATIENTS REFERRED TO ENDOSCOPIC RETROGRADE CHOLANGIOPANCREATOGRAPHY
}

\author{
Ermelindo Della LIBERA, Rodrigo Azevedo RODRIGUES, \\ Ana Paula Rodrigues GUIMARÃES, Gustavo Andrade de PAULO, \\ Stephan GEOCZE and Angelo Paulo FERRARI
}

\begin{abstract}
Background - Sphincter of Oddi manometry is the gold-standard method for sphincter of Oddi dysfunction. The prevalence of sphincter of Oddi dysfunction among patients referred to endoscopic retrograde cholangiopancreatography is largely unknown. Aim - To evaluate prospectively the prevalence of biliary sphincter of Oddi dysfunction (B-SOD) among Brazilian patients referred to endoscopic retrograde cholangiopancreatography and to study the safety of sphincter of Oddi manometry in this setting. Methods - Biliary sphincter of Oddi manometry was intended in 110 patients referred to endoscopic retrograde cholangiopancreatography. The number of attempts to obtain deep cannulation with the manometry catheter was recorded and patients were divided into two groups: up to 5 (easy cannulation) and $>5$ attempts (difficult cannulation). Results - Sphincter of Oddi manometry was successful in 71/110 patients (64.5\%). Sphincter of Oddi dysfunction was found in 18/71 patients (25\%). Endoscopic retrograde cholangiopancreatography findings were: normal in 16, biliary stones in 39 , malignant biliary strictures in 9 and benign biliary strictures in 7 . There was no statistical difference in sphincter of Oddi dysfunction prevalence regarding disease, gender or difficulty of cannulation. Only 2/71 patients developed post-procedure mild pancreatitis. Conclusions - We have found a high prevalence of sphincter of Oddi dysfunction in patients referred to endoscopic retrograde cholangiopancreatography. Gender, nature of disease or difficulty of cannulation did not influence the prevalence of sphincter of Oddi dysfunction among these patients. Sphincter of Oddi manometry is a safe procedure for the evaluation of sphincter of Oddi dysfunction in patients referred to endoscopic retrograde cholangiopancreatography.
\end{abstract}

HEADINGS - Sphincter of Oddi. Cholangiopancreatography, endoscopic retrograde. Bile ducts, physiopathology.

\section{INTRODUCTION}

The sphincter of Oddi (SO) regulates bile and pancreatic juice flow into the duodenum and avoids the occurrence of duodeno-biliary reflux. Many studies in past decades made clear the relationship between the structural or functional obstruction of the sphincter and biliary or pancreatic-like pain. Such abnormality has been called sphincter of Oddi dysfunction (SOD) and it may be the etiology of post-cholecystectomy syndrome and/or recurrent idiopathic pancreatitis ${ }^{(6,19)}$.

Sphincter of Oddi manometry (SOM) is the goldstandard method for SOD diagnosis ${ }^{(9,13)}$ during endoscopic retrograde cholangiopancreatography (ERCP).

A basal pressure (BP) higher than $40 \mathrm{~mm} \mathrm{Hg}$ is the most important parameter used to confirm $\mathrm{SOD}^{(19,22)}$. Drugs thought to have any action on the sphincter (hioscina, morphine, meperidine, atropine, glucagon, nitrates and calcium channel blockers) must be avoided during the procedure ${ }^{(22)}$.

Previous studies have reported the SOD prevalence in patients with post-cholecystectomy syndrome and recurrent idiopathic pancreatitis ${ }^{(3,10,17)}$. The overall prevalence and real clinical importance of SOD among general patients referred to ERCP, however, is unknown.

The aim of this study was to evaluate the prevalence of biliary SOD among patients referred to ERCP and the safety of SOM in such patients.

\section{METHODS}

From August 2001 to September 2002, we conducted a cross-sectional study in patients with suspected biliary disease

Discipline of Gastroenterology, São Paulo Federal University, "Escola Paulista de Medicina" - UNIFESP/EPM, São Paulo, SP, Brazil 
referred to ERCP. All included patients underwent a thorough history and physical examination. Recent laboratorial tests and radiological information were reviewed. Informed consent was obtained from all patients. The study was reviewed and approved by the Ethics and Research Committee of Federal University of São Paulo, SP, Brazil, in accordance with the Declaration of Helsinki.

All procedures were performed on an out-patient basis. Diazepam, midazolan and/or propofol were used for sedation based on individual characteristics. No glucagon, hyoscine n-butyl-bromide, meperidine or droperidol were administered. A triple lumen catheter (SOM-18S-Lehman-NG, Wilson Cook Medical Inc., Winston-Salem, NCUSA) was used for SOM. One channel was reserved for aspiration, contrast injection or guide-wire. The two remaining channels were specific for pressure recording. The catheter was connected to a manometry device (Dynapack MPX 816 - Dynamed Ind. Ltda., São Paulo, Brazil) with continuous water perfusion $(0,25 \mathrm{~mL} / \mathrm{min})$ provided by a calibrated pneumo-hydraulic pump.

Duodenal reference pressure ("zero" baseline pressure) was determined. The papilla was canullated and duct position was confirmed by aspiration of bile. In some cases, a small amount of contrast media was injected to confirm the catheter location.

Basal pressure and pressure curve signals were converted into digital data and sent to a personal computer, provided with appropriated software. After cannulation, the catheter was slowly withdrawn until the sphincter was reached ("pull through" technique), recognized by the appearance of phasic waves. Recording was continue for 2 to 4 minutes. The time required for SOM and the number of cannulation attempts were also recorded. Basal pressure higher than $40 \mathrm{~mm} \mathrm{Hg}$ was the only parameter used for diagnosis of biliary SOD (B-SOD), and SOM was considered successful when a reliable pressure recording was acquired. After SOM, ERCP and any therapeutic procedure were performed as indicated. All patients were contacted (in hospital or by telephone call) the day after the exam. Post-procedure pancreatitis was considered in patients with acute pain and/or tenderness in the upper abdomen and elevated serum amylase (more than 3 times normal upper limit).

All numeric variables were described as median and standard deviation. The Mann-Whitney test was used to compare medians. The categorical variables were represented by absolute (n) or relative frequency $(\%)$ and compared with Chi-square test or Fisher exact test, when applicable. All procedures were conducted at the 0.05 level of significance.

\section{RESULTS}

One hundred and ten patients were enrolled in this prospective study, being 64 (58.2\%) female.

SOM was successfully performed in $71 / 110$ patients (success rate: $64,5 \%$ ). Among the 71 patients, 42 (59\%) were female with a median age of $51 \pm 18$ years. Most of the patients $(86 \%)$ had never undergone ERCP. The most common clinical reasons for indicating the procedure (Table 1) were jaundice of unknown origin and choledocholithiasis suspicion. Other less frequent indications included abdominal pain of unknown origin, suspected biliary or pancreatic neoplasia, sclerosing cholangitis and acute cholangitis.
TABLE 1. Indications for ERCP among patients undergoing successful SOM

\begin{tabular}{lcc}
\hline & $\mathbf{n}$ & $\%$ \\
\hline Jaundice of unknown origin & 37 & 52 \\
Choledocholithiasis suspicion & 18 & 25 \\
Abdominal pain of unknown origin & 6 & 8.5 \\
Suspected biliary neoplasm & 4 & 5.5 \\
Suspected pancreatic neoplasm & 3 & 4 \\
Sclerosing cholangitis & 2 & 3 \\
Acute cholangitis & 1 & 1 \\
\hline
\end{tabular}

SOM was not successful in 39/110. Reasons for not performing manometry were: in 32 patients cannulation with the manometry catheter was not possible and in 3 the pressure recording was not reliable. The papilla could not be reached in three patients (duodenal stricture in two and Billroth II gastrectomy in one) and in another patient a sphincterotomy was present. Only in 10 patients ERCP was not succeeded: failure to cannulate the desired duct in 7, duodenal stricture in 2, Billroth II gastrectomy in 1. A successful ERCP was conducted in the remaining 29 patients without SOM, with the following findings: biliary lithiasis (8), papillary, biliary or pancreatic neoplasia (8), normal study (7), chronic pancreatitis (2), pancreas divisum (1), choledochal cyst (1), sclerosing cholangitis (1) and post-surgical biliary leakage (1).

Among the patients with successful manometry ERCP findings included: gallbladder and/or common bile duct stones in 39/71 (55\%), malignant biliary strictures in 9/71 (12.6\%), benign biliary stricture in 7/71 (9.9\%) and 16/71 (22.5\%) had a normal study (Table 2).

SOD was diagnosed in 18/71 (25\%) patients. Median ages of SOD positive and negative groups were $50 \pm 16.9$ and $47 \pm$ 18.4 , respectively $(P>0,05)$. Seven patients with SOD $(38.9 \%)$ were male, lithiasis was present in eight, normal study in four, malignant biliary stricture in three and benign biliary stricture also in three patients. No statistical difference was found in the prevalence of SOD among the groups.

As shown in Table 2, four patients (three women) with normal ERCP had SOD. Abdominal pain was the reason for ERCP in three of them. According to the Geenen SOD classification ${ }^{(9)}$ two were biliary type III and one biliary type II. The later was submitted to biliary sphincterotomy. The fourth patient had cholestasis due to chronic liver disease.

TABLE 2. ERCP findings among patients undergoing successful SOM

\begin{tabular}{lccc}
\hline & & \multicolumn{2}{c}{ SOD } \\
\cline { 3 - 4 } & $\mathbf{n}(\%)$ & Absent & Present $\left(^{*}\right)$ \\
\hline Stones & $39(55.0)$ & 31 & $8(21)$ \\
Normal study & $16(22.5)$ & 12 & $4(25)$ \\
Malignant biliary strictures & $9(12.6)$ & 6 & $3(33)$ \\
Benign biliary stricture & $7(9.9)$ & 4 & $3(43)$ \\
Total & $71(100.0)$ & 53 & $18(25)$ \\
\hline
\end{tabular}

*: percentages are related to the total number of patients in each group; malignant strictures included cholangiocarcinomas and pancreatic neoplasms; benign strictures included sclerosing cholangitis and post surgery or

postsphincterotomy stenosis
$X^{2}, P>0.05$ 
Cannulation was considered easy (up to five attempts) in 47 patients (66\%) and difficult (more than five attempts) in 24/71 (34\%). In the "easy" group $12(25.5 \%)$ had a basal pressure higher than $40 \mathrm{~mm} \mathrm{Hg}$ (SOD) while $6 / 24$ patients $(25 \%)$ with $>5$ attempts had SOD. No statistical difference was observed in the prevalence of SOD between the two groups.

Post-ERCP/SOM complications were observed in 11/71 patients $(15.5 \%)$, most of them requiring only endoscopic and/or clinical management. Four patients had non-pancreatic self-limited abdominal pain. Two patients who developed post-procedure cholangitis (one due to retained biliary stone and the other with early stent malfunction) had a satisfactory outcome after antibiotics and endoscopic drainage. In a third patient with cholangitis and cholangiocarcinoma, endoscopic therapy was not possible. He was referred to surgery and died because of sepsis three days after surgery. This patient represents the only death related to the procedure (mortality rate $1.4 \%$ ). Two patients $(2.7 \%)$ had mild self-limited pancreatitis and were medically managed. One patient, with poor clinical condition, presented respiratory failure in the last minutes of ERCP, requiring ventilatory support. One patient had post-sphincterotomy bleeding, successfully treated endoscopically. All complications occurred in patients submitted to therapeutic ERCP. There was no statistical difference in the prevalence of complications between patients with or without SOD (Table 3).

Among 47 patients who had an easy cannulation, 5 (10.6\%) developed some complication, compared with 6 of 24 patients $(25 \%)$ in whom more than 5 attempts were necessary, with no statistical difference.

TABLE 3. Presence of complications related to SOD diagnosis

\begin{tabular}{lccc}
\hline & Normal sphincter & SOD & Total \\
\hline No complication & 45 & 15 & 60 \\
Complication & 8 & 3 & 11 \\
Total & 53 & 18 & 71 \\
\hline
\end{tabular}

$P>0.05$ (Fisher exact test)

\section{DISCUSSION}

SOD is defined as a benign, obstructive and non-calculous disorder affecting the SO, leading to abdominal pain, cholestasis and recurrent pancreatitis ${ }^{(15,19)}$.

Endoscopic SOM is considered the gold-standard diagnostic method for $\mathrm{SOD}^{(3,4,9,13)}$. Studies conducted in healthy volunteers were not able to determine the real prevalence of $\operatorname{SOD}^{(8,11,12,14}$ $16,18,25)$. The prevalence and real clinical importance of SOD are also unknown among patients referred to ERCP and this was the main motivation for this study.

Diazepam and/or midazolan have been used routinely during ERCP/SOM. Some authors reported a relaxing effect of midazolan on SO of patients with SOD or with a borderline basal pressure ${ }^{(5,7,20)}$. Therefore, patients with SOD may have been misdiagnosed in our study because of routine use of the drug. Nevertheless, two of these studies had no control groups and dealed with a small number of patients ${ }^{(5,20)}$. The third study, although controlled, was not randomised ${ }^{(7)}$.
SOM was successfully recorded in $64.5 \%$ of the patients, which is similar to published reports ${ }^{(24)}$. We shall emphasize that our patients come from low socio-economic classes frequently with a poor clinical condition.

Even considering our small sample, the high rate of SOD found in our study $(24.7 \%)$ does not seem to have been influenced by age or gender. The nature of disease at ERCP does not seem to alter the prevalence of SOD since there was no difference between patients with gallbladder or ductal stones, normal study, biliary cancer or benign biliary stricture. However, the reduced number of patients precludes statistical analysis and we can not exclude a type B error. Even though, in order to explain such high SOD rate, we wonder if sub-clinical SOD could lead to some biliary change like stones, because of some degree of biliary stasis ${ }^{(2,23)}$, or represents a consequence of any biliary tract disease. There are questions that may be asked: is B-SOD a non-specific response to any biliary disease? Does B-SOD play any role in different biliary diseases? Our study was able to raise these questions but more studies with larger samples, probably stratified by different biliary diseases are needed if we want to have precise answers.

We wonder if the mechanical stimulation due to papillary trauma could increase SO tonus manifested as SOD on manometry. This thesis was not confirmed, since cannulation was considered easy in most (47/71) of our patients. In those who required a greater number of attempts a similar prevalence of SOD was observed.

We have found a low rate of major complications. Since all patients underwent SOM and ERCP at the same procedure, it is difficult to estimate the real role of SOM on complications. Hence, all the patients with complications had a therapeutic procedure during ERCP. Pancreatitis was diagnosed in only two patients, with a mild self-limited course and good outcome in both cases after conservative treatment. Complications were not related to the presence of SOD as shown in Table 3.

Comparing with previous reports on SOD prevalence, we found a higher prevalence in patients referred to $\operatorname{ERCP}^{(1,6,10 \text {, }}$ 17, 19, 21). We were surprised with such finding. However, there is no similar previous report on literature, so our results are not comparable with other studies.

\section{CONCLUSION}

We have found a high prevalence of biliary sphincter of Oddi dysfunction in patients referred to ERCP. This small series can raise the possibility that SOD is more common than thought before. Maybe, the disease presents some type of clinical manifestation in a minority of patients only. Studies with more patients grouped by specific diseases are necessary to establish the role of SOD in biliary diseases.

\section{ACKNOWLEDGEMENTS}

Partially supported by "Fundação de Amparo à Pesquisa do Estado de São Paulo" - FAPESP - Process \#01/02462-4. 
Della Libera E, Rodrigues RA, Guimarães APR, Paulo GA, Geocze S, Ferrari AP. Prevalência da disfunção do esfíncter de Oddi em pacientes encaminhados à colangiopancreatografia retrógrada endoscópica. Arq Gastroenterol. 2007;44(1):18-21.

RESUMO - Racional - Manometria do esfíncter de Oddi é o método padrão-ouro para o diagnóstico da disfunção do esfíncter de Oddi. Atualmente, a prevalência de disfunção do esfíncter de Oddi em pacientes encaminhados a colangiopancreatografia retrógrada endoscópica é desconhecida. Objetivos - Avaliar prospectivamente a prevalência de disfunção do esfíncter de Oddi em pacientes encaminhados a colangiopancreatografia retrógrada endoscópica e estudar a segurança da manometria do esfíncter de Oddi nesses pacientes. Método - Neste estudo, 110 pacientes encaminhados à colangiopancreatografia retrógrada endoscópica foram submetidos a manometria do esfíncter de Oddi biliar. Com base no número de tentativas de canulação da papila os pacientes foram divididos em dois grupos: até cinco tentativas (canulação fácil) e mais de cinco tentativas (canulação difícil). Resultados - Manometria do esfíncter de Oddi foi realizada com sucesso em 71/110 pacientes (64,5\%). Disfunção do esfíncter de Oddi foi encontrada em 18/71 pacientes (25\%). Os achados das colangiopancreatografia retrógrada endoscópica foram: estudo normal em 16, coledocolitíase em 39, estenose biliar maligna em 9 e estenose biliar benigna em 7. Não foi observada diferença estatística na prevalência de disfunção do esfíncter de Oddi considerando-se a natureza da doença, sexo ou a dificuldade de canulação. Somente 2/71 pacientes evoluíram com pancreatite pós-procedimento de leve intensidade. Conclusão - Encontrou-se alta prevalência de disfunção do esfíncter de Oddi em pacientes encaminhados a colangiopancreatografia retrógrada endoscópica. Sexo, natureza da doença ou dificuldade de canulação não mostraram influência na prevalência da disfunção nestes pacientes. Manometria do esfíncter de Oddi mostrou-se um procedimento seguro na pesquisa de disfunção do esfíncter de Oddi em pacientes encaminhados a colangiopancreatografia retrógrada endoscópica.

DESCRITORES - Esfíncter da ampola hepatopancreática. Pancreatocolangiografia retrógrada endoscópica. Ductos biliares, fisiopatologia

\section{REFERENCES}

1. Bar-Meir S, Halpen Z, Bardran E. Frequency of papillary dysfunction among cholecistectomized patients. Hepatology. 1984;4:328-30.

2. Cicala M, Habib FI, Fiocca F, Pallotta N, Corazziari E. Increased sphincter of Odd basal pressure in patients affected by gall stone disease: a role for biliary stasis and colicky pain? Gut. 2001;48:414-7.

3. Corazziari E. Sphincter of Oddi dysfunction. Dig Liver Dis 2003;35 Suppl 3:S26-9.

4. Craig AG, Peter D, Saccone GT, Ziesing P, Wycherley A, Toouli J. Scintigraphy versus manometry in patients with suspected biliary sphincter of Oddi dysfunction. Gut. 2003;52:352-7.

5. Cuer JC, Dapoigny M, Bommelaer G. The effect of midazolam on motility of the sphincter of Oddi in human subjects. Endoscopy. 1993;25:384-6.

6. Eversman D, Fogel E, Rusche M, Sherman S, Lehman G. Frequency of abnormal pancreatic and biliary sphincter manometry compared with clinical suspicion of sphincter of Oddi dysfunction. Gastrointest Endosc. 1999;50:637-41.

7. Fazel A, Burton FR. A controlled study of the effect of midazolam on abnormal sphincter of Oddi motility. Gastrointest Endosc. 2002;55:637-40.

8. Funch-Jensen P, Kruse A, Ravnsbaek J. Endoscopic sphincter of Oddi manometry in healthy volunteers. Scand J Gastroenterol. 1987;22:243-9.

9. Geenen JE, Hogan WJ, Dodds WJ, Toouli J, Venu RP. The efficacy of endoscopic sphincterotomy after cholecystectomy in patients with sphincter-of-Oddi dysfunction. N Engl J Med. 1989;320:82-7.

10. Gilbert DA, DiMarino AJ, Jensen DM, Katon R, Kimmey MB, MacFadyen BV Michaletz-Onody PA, Zuckerman G. Status evaluation: sphincter of Oddi manometry. American Society for Gastrointestinal Endoscopy. Technology Assessment Committee. Gastrointest Endosc. 1992;38:757-9.

11. Gregg JA, Carr-Locke DL. Endoscopic pancreatic and biliary manometry in pancreatic, biliary, and papillary disease, and after endoscopic sphincterotomy and surgical sphincteroplasty. Gut. 1984;25:1247-54.

12. Guelrud M, Mendoza S, Rossiter G, Villegas MI. Sphincter of Oddi manometry in healthy volunteers. Dig Dis Sci. 1990;35:38-46.

13. Guelrud M. How good is sphincter of Oddi manometry for chronic pancreatitis? Endoscopy. 1994;26:265-7.
14. Kalloo AN, Pasricha PJ. Effect of gastric distension and duodenal fat infusion on biliary sphincter of Oddi motility in healthy volunteers. Dig Dis Sci. 1995;40:745-8.

15. Lehman GA, Sherman S. Sphincter of Oddi dysfunction. Int J Pancreatol. 1996;20:11-25

16. Meshkinpour H, Mollot M, Eckerling GB, Bookman L. Bile duct dyskinesia. Clinical and manometric study. Gastroenterology. 1984;87:759-62.

17. Neoptolemos JP, Bailey IS, Carr-Locke DL. Sphincter of Oddi dysfunction: results of treatment by endoscopic sphincterotomy. Br J Surg. 1988;75:454-9.

18. Okazaki K, Yamamoto Y, Ito K. Endoscopic measurement of papillary sphincter zone and pancreatic main ductal pressure in patients with chronic pancreatitis. Gastroenterology. 1986;91:409-18.

19. Petersen BT. An evidence-based review of sphincter of Oddi dysfunction: part I, presentations with "objective" biliary findings (types I and II). Gastrointest Endosc. 2004;59:525-34.

20. Rolny P, Arleback A. Effect of midazolam on sphincter of Oddi motility. Endoscopy. 1993;25:381-3.

21. Sherman S, Troiano FP, Hawes RH, O'Connor KW, Lehman GA. Frequency of abnormal sphincter of Oddi manometry compared with the clinical suspicion of sphincter of Oddi dysfunction. Am J Gastroenterol. 1991;86:586-90.

22. Sherman S, Lehman GA. Sphincter of Oddi dysfunction: diagnosis and treatment. JOP. 2001;2:382-400.

23. Ugljesic M, Bulajic M, Milosavljevic T, Stimec B. Endoscopic biliary manometry in cholecystectomized patients with and without choledocholithiasis. Hepatogastroenterology. 1998; $45: 651-5$.

24. Venu RP. The role of the endoscopist in sphincter of Oddi manometry. Gastrointest Endosc Clin N Am. 1993;3:67-80.

25. Viceconte G, Micheletti A. Endoscopic manometry of the sphincter of Oddi: its usefulness for the diagnosis and treatment of benign papillary stenosis. Scand $\mathrm{J}$ Gastroenterol. 1995;30:797-803. 